DOI: $10.17805 /$ zpu.2017.2.8

\title{
Эволюция погребального обряда хакасов: факторы сохранения системной целостности *
}

\author{
Л. В. АНЖИГАНОВА, М. Ю. АРЧИМАЧЕВА \\ ХАКАССКИЙ ГОСУДАРСТВЕННЫЙ УНИВЕРСИТЕТ ИМ. Н. Ф. КАТАНОВА
}

В работе осуществлен анализ основных этапов и факторов эволюции погребального обряда хакасов начиная с древности до начала XXI в. Под понятием «погребальный обряд» авторы понимают систему действий, объединенных единством мировоззренческих оснований, совершаемых с момента смерти человека, во время погребения и после похорон в виде поминальных ритуалов. Анализ научной литературы показал, что погребальный обряд рассматривался как объект либо археологических, либо этнографических изысканий, а также что потребность рассмотреть обряд в его системной целостности требует культурологического анализа.

Погребальный обряд хакасов в своих мировоззренческих основах начал формироваться еще в период тагарской культуры VIII-II вв. до н. э. Он соответствовал вертикально-горизонтальной структуре мира, проводился в соответствии с культами Неба, Земли, Огня. Таковым он оставался и в последующие периоды развития народа.

B XVIII - начале XXI в. обрядность испытала влияние ряда факторов, в большей степени повлиявших на форму, но не на содержание ритуалов. Так, влияние господствующего рода кыргызов выразилось в доминировании обряда по типу трупосожжения. Взаимодействие различных этнических групп и родов (сеоков) Саяно-Алтая также внесло некоторые новации в обряд и оформление памятников. Особое влияние на проведение погребального обряда хакасов могла бы оказать христианизация, но он сохранил свою целостность. Атеизм XX в. лишь изменил форму надгробного памятника, когда распространились постаменты с пятиконечной звездой. В XXI в. происходит восстановление этнической культуры хакасов. Хакасы выказывают живой интерес к традиционным формам, в том числе в погребальной обрядности.

Ключевые слова: погребальный обряд; хакасы; кыргызы; этническая культура; эволюция обряда; факторы культуры; системная целостность

\section{BВЕАЕНИЕ}

Э тнические культуры под натиском глобализации и модернизации все больше утрачивают собственную целостность. Элементы этнической культуры, имея разную степень исторической устойчивости, все больше и больше универсализируются: мы вовлечены в общие экономические, политические и социокультурные процессы. ОАнако наибольшую живучесть демонстрируют традиции, связанные с ритуалами, обслуживающими проблемы жизни и смерти. Среди обрядов жизненного цикла погребальный обряд принадлежит к фундаментальным основам человеческого бытия, так как в нем в наиболее яркой форме проявляется символическая природа Жизни и Смерти. Под понятием «погребальный обряд» нами понимается система действий, совершаемых с момента смерти человека, во время погребения и после похорон в виде поминальных ритуалов, характеризующаяся единством мировоззренческих оснований и установок. Соответственно, погребальный обряд этноса отражает мировоззренческую целостность этнической культуры.

* Работа подготовлена в рамках реализации проекта РФФИ № 15-03-00146 «Мир женщины: эволюция ценностей, символов, ритуалов».

The work was prepared within the framework of the project supported by the RFBR № 15-03-00146 «The woman's world: the evolution of values, symbols, rituals». 
Проблема сохранения и развития этнической культуры в условиях глобализации чрезвычайно актуальна и для хакасов. Настоящая работа посвящена изучению погребального обряда коренного населения Хакасско-Минусинской котловины, являющегося одним из этнически значимых элементов культуры народа: не только как части культурного наследия, но и активно функционирующим сегодня. Практическая необходимость изучения погребального обряда хакасов связана и с тем, что при его совершении нередки разночтения в отдельных элементах ритуалов. Это позволяет предположить, что погребальный обряд хакасов мог претерпеть некоторые изменения в ходе долгого исторического развития этноса. Однако это ставит вопрос: насколько при этом сохранилась системная целостность погребального обряда этноса?

В данной статье нами поставлена цель - осуществить анализ основных этапов и факторов эволюции погребального обряда хакасов начиная с древности до начала XXI в.

Методологической основой исследования является комплексный подход к изучению погребального обряда этноса, основанный на совокупности приемов и методов системно-структурного, семиотического, синхронно-диахронного, герменевтического анализов.

\section{ПОГРЕБААЬНЫЙ ОБРЯА ХАКАСОВ КАК ОБЪЕКТ НАУЧНОГО ИССАЕАОВАНИЯ}

При анализе формирования и развития погребального обряда, как и всей культуры хакасского этноса, одной из наиболее актуальных проблем является корреляция археологического, этнографического и фольклорного материала с современной культурой народа. В работе авторы не ставят специальной задачи углубленного анализа всей имеющейся научной литературы по избранной проблематике, ограничиваясь констатацией его сложного междисциплинарного характера.

Погребальный обряд хакасов исследователями-археологами, как правило, рассматривался прежде всего через изучение погребальных памятников и вещественного материала (Иипский, 1963). Однако среди подобного рода работ можно встретить и серьезные исследования мировоззренческих основ погребального обряда (Кызласов, 1975, 1993).

Первые этнографические описания погребального обряда хакасов появились в XVIII в. Аля ученых XVIII в. погребальный обряд хакасов и захоронения не являлись предметом специального изучения, но уже заметно стремление отдельных авторов увязать различные способы обращения с умершими с этническими группами хакасов и их религиозными воззрениями. Аореволюционными авторами (Образцы ... , 1907; Майногашев, 1915) в основном уделялось внимание духовной культуре и традиционно-бытовой обрядности хакасов в контексте происходящей трансформации этнической культуры народа в связи с присоединением Сибири к Российской империи. В советское время погребальный обряд хакасов обстоятельно исследовал В. Я. Бутанаев (Бутанаев, 1989).

Обзор исследований погребального обряда хакасов в XVIII - начале XX в. позволяет сделать вывод, что на протяжении длительного периода погребальный обряд являлся прежде всего объектом археологического и этнографического исследования. В научный оборот были введены многочисленные памятники погребальной обрядности, однако комплексного анализа этого консервативного элемента этнической культуры народа в единстве его мировоззренческих оснований, эволюции исторических форм и места в этнической культуре не осуществлялось. Не были рассмотрены и факторы эволюции погребального обряда этноса. 


\section{ПОГРЕБААЬНЫЙ ОБРЯА ХАКАСОВ: \\ ИСТОРИЯ ФОРМИРОВАНИЯ И МИРОВОЗЗРЕНЧЕСКИЕ ОСНОВЫ}

Этническая культура любого народа, с одной стороны, является исторически устойчивым явлением. Непрерывность развития ей придают мировоззренческие универсалии, символы и ценности, которые передаются от поколения к поколению. С другой стороны, мы не знаем, пожалуй, ни одной культуры, не испытавшей инокультурного влияния. Поэтому так важно исследовать этническую культуру в единстве процессов устойчивости и изменчивости.

Жизнестойкость хакасского этноса, как и любого другого, находится в прямой зависимости от состояния культурного наследия. В процессе сложения и дальнейшего развития этнос всегда ищет способы утверждения настоящего и будущего. Объекты материальной культуры прошлого хакасов, от палеолита до Средневековья, свидетельствуют об определенном культурно-психологическом складе древнего населения и его взаимоотношениях с окружающим миром. Памятники археологических эпох Минусинских степей несли не только отпечаток принадлежности к определенному кругу древних культур, но и выполняли сакральные и идеологические функции по отношению к освоенному пространству и времени, на основе чего формировался традиционный культ предков и вырабатывался целостный образ мира.

Особые благоприятные природные условия Хакасско-Минусинской котловины способствовали интенсивным историческим, этническим процессам и сложению своеобразных и ярких культур. В течение тысячелетий на данной территории в ходе передвижений населения из сопредельных регионов Северной и Центральной Азии формировались новые этнические общности и культурные традиции, влияющие на все стороны жизни, в том числе и на погребальный обряд.

Ярким свидетельством такого развития на территории Минусинских степей является тагарская культура VIII-II вв. до н. э., представленная монументальными курганами, предметами высокого бронзового мастерства и проч. Аля людей тагарской культуры был характерен взгляд на природу как на движущийся и циклично изменяющийся мир, в котором происходит борьба добрых и злых сил. Единство мира символизировали Арево Жизни, мировая Гора, Небо, Солнце, солярные круги, оленные бляхи. Модель мира нашла свое воплощение в строительстве курганов данной эпохи. Воздействуя на сознание и чувства людей своей монументальностью, в которой воплощалась социально-психологическая функция власти, окруженной ореолом сакральности, небесной святости, погребальные памятники формировали тем самым культ предков и всего того, что с этим культом было связано.

На основе тагарской культуры на рубеже нашей эры в эпоху Великого переселения народов сложилась таштыкская культура (I-IV вв.). Тюркоязычные полукочевые племена, вытесненные хуннами из Западной Монголии, положили начало формированию на Среднем Енисее данной культуры, памятниками которой являются грунтовые могилы, склепы, помины-жертвенники в виде ритуальных ямок со стелами. В таштыкских склепах были обнаружены мумии, в грунтовых могилах - в большом количестве предметы конского снаряжения, свидетельствующие о том, что конь в жизни таштыкцев играл существенную роль. Все это свидетельствует о разделении пространства на «этот» земной и «иной» подземный миры, о том, что были представления о возможности перехода из одного в другой мир.

Несмотря на то что рассмотренные археологические культуры относятся к разным этническим общностям, процесс освоения памятников новыми поколениями людей 
шел по пути «распредмечивания» их сущности. В памятниках прошлого воплощались мировоззренческие, религиозные, нравственные, әстетические идеи, отсюда их способность выступать в роли носителя культурной и социальной информации, памяти, объективированной предметно-деятельностной и творческой природы человека. Не случайно воплощенные в курганах культы (предков, семейно-родовых святынь, солнца и небесного огня, растительных сил природы) мы наблюдаем в течение всей эволюции погребального обряда хакасов.

В кыргызский период Аревнехакасского каганата (VI-VIII вв.) продолжает нарастать системная сложность культуры народа. Это проявляется в увеличении этнической мозаичности, использовании в государственных целях енисейской рунической письменности, сосуществовании различных религиозных систем и духовных практик (тенгрианство, шаманизм, буддизм).

Несмотря на то что внутренние и внешние факторы влияния подрывали стабильность этноса, неизменным для этноса и погребального обряда как элемента этнической культуры оставался пространственно-временной и культурный континуум. Погребальный обряд по своей мировоззренческой направленности мало чем отличается от обрядов предшествующей эпохи.

В последующие «темные века» истории Хакасии в XII-XVIII вв. вследствие монгольского завоевания, утраты самостоятельности и катастрофического уменьшения населения этническая система стала упрощаться, и здесь мы не обнаруживаем уже своеобразных и ярких археологических культур. В целом такое состояние можно было бы назвать регрессом, так как была утрачена государственность, в социальной структуре этнос восстановил прежде доминировавшие семейно-родственные отношения. Ауховным стержнем народа остался шаманизм как естественная основа мировоззрения.

\section{ОСНОВНЫЕ ФАКТОРЫ ЭВОАЮЦИИ ПОГРЕБААЬНОГО ОБРЯАА XАKАCOB XVIII-XXI BEKOB}

В последующие века, XVIII - начале XXI в., погребальный обряд и погребальные памятники хакасов стали отличаться все большим разнообразием. Анализ эволюции погребального обряда и этническая интерпретация памятников этого периода позволили выделить ряд факторов, повлиявших на рост разнообразия форм погребального обряда.

1. Взаимодействие в XVIII в. различных этнических групп Саяно-Алтая в Хакасско-Минусинской котловине (Бутанаев, 1990: 82). Они консолидировались вокруг незначительного числа оставшихся и вернувшихся из угона 1703 г. кыргызов и вошли в состав родоплеменных групп хакасов. Включение в состав хакасского этноса разноэтнического населения находит подтверждение в сопоставлении многих деталей обрядовости у хакасов и народов Саяно-Алтая. Например, кумандинцы, теленгиты, телесы, алтай-кижи, тувинцы, шорцы, так же как хакасы, использовали «воздушный» способ погребения младенцев на дереве, шаманов на помосте, грунтовые захоронения в колодах, гробах и без них. Теленгиты, телесы, алтай-кижи практиковали трупосожжение. Тубалары и челканцы в могилах сооружали рамы из плах и досок, с широким применением бересты, войлока. Алтай-кижи, тувинцы во время погребального обряда осуществляли жертвоприношение коня. Кумандинцы, тувинцы делали в могиле деревянный навес над гробом. Перечисленные народы Саяно-Алтая сооружали деревянный столбик на могиле некрещеного умершего, а теленгиты, телесы, тувинцы надмогильный деревянный «домик». 
2. Аоминантное влияние кыьгызской культуры на погребальный обряд хакасов. В ходе исторического развития раздичные социально-этнические группы региона подверглись сильному влиянию кыргызской культуры.

Истоки погребального обряда хакасов уходят в эпоху раннего Средневековья со времени появления кыргызов в Минусинской котловине. Среди погребальных памятников на территории Хакасско-Минусинской котловины ко времени вхождения Хакасии в состав Российской империи по способу погребения можно выделить погребения по обряду трупосожжения и трупоположения, что свидетельствует о наличии разноэтнического населения и сложности исторического и этногенетического процессов на данной территории.

По этнической принадлежности погребения по обряду трупосожжения относят к кыргызскому населению (Бутанаев, Худяков, 2000: 110). Судя по обряду кремации, в религиозных представлениях кыргызов, как и у древних тюрков, важное место занимал культ огня. Согласно мифологической версии человек считал, что мир образован четырьмя мировыми стихиями: водой, землей, огнем и воздухом. Огонь рассматривается как важнейший из первоэлементов, так как является символом самого Отца творения мира. Отсюда его основная характеристика - порождение, творчество. Огонь разрушает все, но и очищает. Необходимость очищения предполагает наличие в системе религиозных представлений идеи о загробной жизни. Огонь выступает в качестве проводника, «моста» в загробный мир. При помощи очистительных обрядов, возможно, стирается земная информация при переходе в «другой» мир. Амбивалентность сущности огня как подателя жизни и символа смерти сливается в обрядности в одном значении - необходимости получения благополучия для души умершего.

Важную роль в понимании смысла отдельных вещей играет контекст их использования, в котором устанавливаются их связи с другими вещами и с ситуацией, в которой их применили. Не случайно ассоциация огня с Солнцем, как источником жизни и плодородия, была воплощена в форме круга и отразилась в возведении могильных круглых оград в афанасьевской (III тыс. до н. э.), андроновской (XII-XI вв. до н. э.) культурах и в период Средневековья в виде кольцевых каменных и овальных земляных насыпей над могилой. Возведение надмогильного сооружения в виде круга олицетворяло, с одной стороны, полноту, завершенность погребения, подобно циклическому движению солнца, с другой стороны - замкнутость, создание защитного пространства вокруг умершего, а с третьей стороны - защиту живых сородичей от душ умерших и подземного мира. Таким образом, культ огня и Солнца получил целостный образ в погребальной обрядности. Погребения по способу трупосожжения существовали также у алтайцев и тувинцев, близкородственных хакасам народов.

В археологических материалах практически не фиксируется часть обряда кыргызов до сожжения. Известно, что умершего сжигали в одежде с бытовыми предметами, предметами вооружения и принадлежностями конского убранства. В ряде случаев отмечена преднамеренная порча вещей. Установлено, что перенос кальцинированных костей с сопроводительным инвентарем на место погребения совершался через некоторое время и сопровождался выборкой ямы. Кальцинированные остатки помещали в некую емкость (Алужневская, 1989: 134-136).

Реминисценцией погребального обряда по способу кремации является обряд кормления предков, во время которого пищу бросали в огонь. Поднимающееся при этом пламя с дымом огня уносило ее наверх, т. е. на Небо. В традиционном представ- 
лении хакасов, вероятно с позднего Средневековья, происходит синкретизм восприятия местоположения загробного мира, который в трехчленной вертикали мироустройства располагали в подземной области и при этом также устраивали поминальный костер, с дымом которого передавали или «кормили» дух умершего.

Культ предков начинает обретать значение в процессе перехода к оседлости и в условиях изменения социальных отношений в коллективе, когда большую роль начинают играть семья, род. На рубеже I-II тыс. появляется иная концепция обитания умерших - «страна мертвых» как бы приближается к «миру живых», и души умерших предков незримо стали присутствовать в делах и судьбах своих потомков, тогда и возникает обряд «кормления».

Таким образом, противоречие между мифологической и социальной структурой вело к трансформации или формированию новой мировоззренческой модели, новых ритуалов и обрядовости в целом.

Погребения по обряду трупоположения в грунтовых могилах впервые появляются в Минусинской котловине в VI-VIII вв. По этнической принадлежности погребения по обряду трупоположения XVIII в. исследователи относят либо к кыштымам, либо к тюркоязычным «енисейским племенам», т. е. зависимому населению (Худяков, 1983: 145). Кыштымы, или «черные люди», являлись иноплеменными данниками из числа различных по языку и происхождению племен и родов Саяно-Алтайского нагорья и бассейна реки Чулым и проживали на территории кыргызских владений.

Погребальный обряд кремации осуществлялся в соответствии с культом Неба, а значит, связан с поклонением Солнцу, огню. Погребение же умершего по обряду трупоположения соответствовало культу Земли, которая, как известно, не только дарует, но и забирает жизнь. Квадратная или прямоугольная форма могилы и всего кладбища также позволяет предположить, что данный обряд символизирует поклонение Земле. Целостность скелета, наличие при нем сопроводительного инвентаря подчеркивают связь покойного с земным миром.

Квадратная форма связывается не только с культом плодородия, но и с культом смерти: в лоне Земли в течение первых трех лет зарождается новая жизнь, и каждое рождение воспринимается как перевоплощение души предка. Четырехугольная могила под овальной земляной насыпью воспроизводит модель мира в его вертикальной и горизонтальной проекциях. Так, надмогильная насыпь захоронения воплощает идею верхнего мира, что заменило идею пути дыма огня. Пространство на уровне погребенной почвы - средний мир, само погребение ниже уровня почвы - нижний мир, символизирующий мир смерти. Надмогильная насыпь, как и форма курганной насыпи, воплощает идею мировой горы - прародительницы.

В погребениях умершие ориентированы головой в основном в западном направлении (северо-западном или юго-западном). Это свидетельствует, видимо, о наличии представлений о горизонтальной структуре мира и местообитании страны умерших. Погребения по обряду трупоположения и связанный с ним весь комплекс погребально-поминальной обрядности нацелены на то, чтобы поддерживать связь двух миров: мира людей и мира мертвых.

Кремация предполагала полное уничтожение телесных останков человека с тем, чтобы он (умерший), очистившись от связей с земным существованием, превратившись в искупительную жертву, смог вернуться в беспредельное пространство. Функция кремации нацелена на то, чтобы подготовить окончательный переход в иной мир, полностью уничтожить следы его социальных связей и личных поступков. 
Погребение же по обряду трупоположения предполагает сохранение целостности останков, дабы такими же они остались в подземном мире. Отсюда можно выдвинуть предположение, что при помощи обряда кремации человек пытался выразить бесконечность мироздания, где сам он и любой предмет являются лишь песчинками. При помощи же обряда трупоположения человек структурирует пространство, в котором выделяются центр и периферия, вертикальное и горизонтальное направления, верх и низ. Общим в совершении обряда кремации и захоронении умершего в землю является представление о том, что смерть выражает изменение состояния, вхождение в мир, отличный от мира живых, допуск к инобытию. Оформление погребального обряда ярко свидетельствует о вертикально-горизонтальном и пространственно-временном структурировании картины мира в традиционном представлении хакасов.

Таким образом, мы видим, что эволюция погребального обряда от кыргызов до так называемых енисейских племен - от трупосожжения до трупоположения - осуществлялась в рамках единой картины мира. В ней жизнь человека представляет круговорот в трех мирах - Верхнем, Среднем, Нижнем. Здесь меняются акценты - от доминирующего культа огня хакасы переходят к культу земли. Кочевники становятся более оседлыми, меняются виды хозяйственной деятельности и тип государственного устройства. Однако мировоззренческая картина населения Хакасско-Минусинской котловины остается единой, культ огня сохраняется и при погребальном обряде сжигании погребальной пищи.

3. Влияние родовой структуры на особенности погребального обряда хакасов. В течение XVIII-XIX вв. у хакасов, помимо административно-родового деления, бытовала традиционная форма социально-этнического разделения по сеокам (букв. кость), оформившаяся задолго до вхождения в состав России. После присоединения Хакасско-Минусинской территории к Российскому государству некоторые сеоки и родовые группы приобрели новые названия. Поэтому один и тот же вид погребального обряда существовал у разных родовых групп. Так, например, все родовые группы хакасов (качинцы, сагайцы, бельтыры, койбалы, кызыльцы) с конца XVII до XX в. применяли следующие захоронения: надземное или «воздушное» захоронение (на дереве, на помосте); погребение в грунтовой яме под овальной насыпью, обложенной каменными плитами. Аетей в возрасте до 3-7 лет и шаманов погребали в стороне от родовых кладбищ. В обряде широко применялись береста, войлок, дерево, сопроводительный инвентарь, жертвоприношение коня и др. Разнообразие погребального обряда по родовому признаку подтверждает, что центральное место в традиционном обществе хакасов занимает род, который выполняет ряд функций:

- является носителем генетической информации этноса;

- организует внутри- и межродовое взаимодействие, ориентированное на сохранение и развитие народа;

- иерархизирует структуру этнических внутригрупповых отношений на основе господствующих и доминируемых родов.

Роль родовых структур в развитии традиционного общества менялась в зависимости от стадии развития этноса. В моменты этнического взлета на первый план выходили, например, такие структуры, как государство. В периоды этнического надлома род восстанавливал свое значение, поскольку, как отмечал П. Сорокин, «единство крови было и остается условием, необходимым для существования множества процессов взаимодействия и бытия коллективных единств... генеалогия рода есть не что 
иное, как взаимодействие ряда поколений, создающееся на почве единства крови... в ряде случаев она является последним прибежищем, ultimum refigium социальной связи и непрерывности» (Сорокин, 1993: 370).

4. Влияние христианизачии на погребальный обряд хакасов. Территория Хакасско-Минусинской котловины в XVIII в. была включена в состав Российского государства. Христианизация местного населения, последовавшая за этим, отразилась на погребальном обряде родоплеменных групп хакасов. Например, после сооружения надмогильного холма над головой крещеных умерших ставили деревянные кресты, над некрещеными - символизирующие Мировое Арево деревянные столбики.

Стало распространенным посещение кладбища в так называемый родительский день. Между тем известно, что в дохристианские времена хакасы последние поминки проводили в три года, так как считали, что после этого душа родственника уже перевоплотилась в потомках.

5. Влияние атеистической традичии на погребальный обряд хакасов. В середине $\mathrm{XX}$ в. под воздействием единой идеологии был нивелирован по стандартному образцу и погребальный обряд. Умерших стали хоронить на специально отведенных городских (сельских) кладбищах с возведением памятников в виде тумбы с красной звездой. Аля известных людей стали организовываться торжественные панихиды, в прессе публиковались некрологи. Похоронные процессии сопровождались музыкой духовых оркестров.

3десь необходимо отметить, что многие обряды жизненного цикла хакасов (имянаречение, свадьба и пр.) в советский период практически изменились полностью как по содержанию, так и по форме. Однако погребальный обряд, несмотря на вышеназванные новшества, в своей основе остался традиционным - обязательными были «кормление» покойного через костер на кладбище, снаряжение его в загробную жизнь, полный цикл поминальных обрядов и пр. Сохранило устойчивость представление о том, что усопшего в Нижний мир надо провожать всем родом, поэтому у хакасов похороны и поминки всегда были особенно многолюдными. А помощь, оказываемая родственниками, помогала семье покойного справиться с нелегким материальным бременем.

6. Влияние прочессов этнического возрождения на осмысление погребального обряда хакасов. В конце XX - начале XXI в. в ходе развернувшегося процесса национального возрождения хакасы стали испытывать потребность рационального осмысления этнической культуры как целостности в единстве мировоззренческих оснований и обрядово-ритуальной практики. Вопросы «Почему?», «Как?», «Аля чего?», «Какой в этом смысл?» и пр., касающиеся нюансов проведения погребального обряда, были обращены не только к старшему поколению, но и к науке. Это породило устойчивый интерес общественности к формированию единой системь погребального обряда, включающей общие и понятные мировоззренческие основы, четкую структуру самого обряда и поминальной практики, единого толкования символов. Нередкими стали призывы к научной интеллигенции подготовить методические пособия по проведению обрядов жизненного цикла, особенно погребального обряда.

В разных районах Хакасии при проведении похоронно-поминального обряда наблюдается стремление местного населения (не только старшего, но и молодого возраста) возродить традиции, символы, ритуалы, обычаи, в том числе правильно расположить сопроводительный инвентарь, проведение «ночных бдений» в доме покойного, обязательное руководство обрядом пожилых людей, «кормление» умершего дома 
и на кладбище, разведение поминального костра (который стал проводиться и в городе во дворах многоэтажных домов), троекратный обход могилы и др.

\section{ЗАКАЮЧЕНИЕ}

Таким образом, анализ эволюции погребального обряда хакасов позволяет представить его как открытую сложноорганизованную развивающуюся систему, на особенности которой повлияли сложные и длительные пространственно-временные факторы развития этноса.

Будучи сформированным в своих мировоззренческих основах еще в тагарской культуре VIII-II вв., погребальный обряд хакасов сохранил системную целостность. В нем мы можем вычленить строгое соответствие структуре мира (Верхний, Средний и Нижний миры), культы Неба, Земли, Огня.

На этапе этнического взлета (в эпоху кыргызского государства) основные ценности народа были ориентированы на развитие, что выразилось в выстраивании «вертикали» в культуре: доминировал культ Неба (огня), куда уходили души умерших. На этапе выживания (после монгольского завоевания и далее) основные ценности были, условно, «горизонтально ориентированы»: доминировал культ Земли, защитой этноса занимались родовые предки.

Несмотря на внутренние и внешние факторы (войны, межкультурное взаимодействие и пр.), неизменным для этноса и погребального обряда как элемента этнической культуры оставался пространственно-временной и культурный континуум. Погребальный обряд по своей мировоззренческой направленности мало чем отличается от обрядов предшествующей эпохи.

Сегодня, в условиях восстановления этнической культуры хакасов в ее полноте и целостности, особый интерес у представителей этноса вызывают мировоззренческие основы, структура погребального обряда, единое толкования символов.

\section{СПИСОК АИТЕРАТУРЫ}

Бутанаев, В. Я. (1989) Погребально-поминальные обряды хакасов в XIX - начале XX вв. // Историко-культурные связи народов Южной Сибири. Абакан : ХакНИИЯАИ. С. 107-132.

Бутанаев, В. Я. (1990) Этническая история хакасов XVII-XIX вв. // Материалы к серии «Народы Советского Союза». Вып. III. М. : ИЭиЭА им. Н. М. Миклухо-Маклая АН СССР. 273 с.

Бутанаев, В. Я., Худяков, Ю. С. (2000). История енисейских кыргызов. Абакан : Изд-во ХГУ им. Н. Ф. Катанова. 272 с.

Алужневская, Т. А. (1989) Погребально-поминальная обрядность кыргызов и шаманский погребальный обряд тюркоязычных народов Саяно-Алтая и Южной Сибири // Жречество и шаманизм в скифскую эпоху. СПб. : Наука. 202 с. С. 134-136.

Кызласов, И. А. (1993) Мировоззренческая основа погребального обряда // Российская археология. № 1. С. 98-112.

Кызласов, А. Р. (1975) Курганы средневековых хакасов (аскизская культура) // Первобытная археология Сибири / отв. ред. А. М. Мандельштам. А. : Наука. 221 с. С. 193-211.

Аипский, А. Н. (1963) Афанасьевское в карасукской эпохе и карасукское у хакасов // Материалы и исследования по археологии, этнографии и истории Красноярского края. Красноярск : Красноярское книжное изд-во. 165 с. С. 57-78.

Майнагашев, С.А. (1915) Загробная жизнь по представлению турецких племен Минусинского края // Живая старина. Петроград : Типография В. А. Смирнова. С. 277-292.

Образцы народной литературы тюркских племен, изданные В. Радловым (1907). Часть IX: Наречия урянхайцев (сойотов), абаканских татар и карагасов. Тексты, собранные и переведенные Н. Ф. Катановым. Перевод. СПб. 658 с. 
Сорокин, П. А. (1993) Система социологии : в 2 т. М. : Наука. Т. 1. 448 с.

Худяков, Ю. С. (1983) Погребение по обряду трупоположения // Историческая этнография: традиции и современность. Вып. 2. $\Lambda$. : Издательство Иенинградского университета. С. 141-148.

Aата поступления: 28.02.2017 2.

\section{THE EVOLUTION OF THE KHAKAS FUNERARY RITE: \\ FACTORS PRESERVING SYSTEMIC INTEGRITY \\ L. V. ANZHIGANOVA, M. Y. ARCHIMACHEVA \\ KATANOV KHAKASS STATE UNIVERSITY}

The work analyzes the main stages and factors of the evolution of the Khakas funerary rite, beginning from antiquity to the early 21 st century. By the term «funerary rite», the authors understand a system of actions united by the unity of world views, performed from the moment of a person's death, during burial and after funeral in the form of memorial rituals. The analysis of the scientific literature has allowed to conclude that the funerary rite was considered either as an object of archaeological or ethnographic research; also, the need to consider the rite in its systemic integrity requires a cultural analysis.

The burial rite of the Khakas in its ideological foundations began to be formed in the Tagar culture of the 8th -2 nd centuries B.C. It corresponded to the vertical-horizontal structure of the world, was conducted in accordance with the cults of Heaven, Earth, and Fire. It remained the same in the subsequent periods of the development of the nation.

In the 18th - early 21st centuries, ceremonial rites were influenced by a number of factors that had a greater impact on the form, but not on the content of rituals. Thus, the influence of the dominant Kyrgyz clan was expressed in the domination of the ritual by the type of cremation. The interaction of various ethnic groups and clans (seoks) of the Sayano-Altai region also introduced some innovations in the ritual and design of monuments. Christianization could have had a special impact on the conduct of the funerary rites of the Khakas but the funeral rite has preserved its integrity. The atheism of the 20th century only changed the shape of the monument (a pedestal with a five-pointed star instead of a tombstone). In the 21st century, the restoration of the ethnic culture of the Khakas takes place. The Khakas showed a great interest to traditional forms including forms of funerary rites.

Keywords: funerary rite; the Khakas; the Kyrgyz; ethnic culture; evolution of the rite; cultural factors; systemic integrity

\section{REFERENCE}

Butanaev, V. Ia. (1989) Pogrebal'no-pominal'nye obriady khakasov v XIX - nachale XX vv. In: Istoriko-kul'turnye sviazi narodov Iuzbnoi Sibiri. Abakan : KhakNIIIaLI. Pp. 107-132. (In Russ.).

Butanaev, V. Ia. (1990) Etnicheskaia istoriia kbakasov XVII-XIX vv. / Materialy k serii «Narody Sovetskogo Soiuza». Vol. III. Moscow, IEiEA im. N. M. Miklukho-Maklaia AN SSSR. 273 p. (In Russ.).

Butanaev, V. Ia. and Khudiakov, Iu. S. (2000). Istoriia eniseiskikb kyrgyzov. Abakan, Izd-vo KhGU im. N. F. Katanova. 272 p. (In Russ.).

Dluzhnevskaia, T. D. (1989) Pogrebal'no-pominal'naia obriadnost' kyrgyzov i shamanskii pogrebal'nyi obriad tiurkoiazychnykh narodov Saiano-Altaia i Iuzhnoi Sibiri. In: Zhrechestvo i shamanizm $v$ skifskuiu epokbu. St. Petersburg, Nauka. 202 p. Pp. 134-136. (In Russ.).

Kyzlasov, I. L. (1993) Mirovozzrencheskaia osnova pogrebal'nogo obriada. Rossiiskaia arkbeologiia, no. 1, pp. 98-112. (In Russ.).

Kyzlasov, L. R. (1975) Kurgany srednevekovykh khakasov (askizskaia kul'tura). In: Pervobytnaia arkbeologiia Sibiri, ed. A. M. Mandel'shtam. Leningrad, Nauka. 221 p. Pp. 193-211. (In Russ.).

Lipskii, A. N. (1963) Afanas'evskoe v karasukskoi epokhe i karasukskoe u khakasov. In: Materialy $i$ issledovaniia po arkheologii, etnografii $i$ istorii Krasnoiarskogo kraia. Krasnoiarsk, Krasnoiarskoe knizhnoe izd-vo. 165 p. Pp. 57-78. (In Russ.). 
Mainagashev, S. D. (1915) Zagrobnaia zhizn' po predstavleniiu turetskikh plemen Minusinskogo kraia. In: Zhivaia starina. Petrograd : Tipografiia V.D. Smirnova. Pp. 277-292. (In Russ.).

Obraztsy narodnoi literatury tiurkskikb plemen, izdannye V. Radlovym (1907). Vol. IX: Narechiia uriankhaitsev (soiotov), abakanskikh tatar i karagasov. Teksty, sobrannye i perevedennye N. F. Katanovym, transl. St. Petersberg. 658, [2] p. (In Russ.).

Sorokin, P. A. (1993) Sistema sotsiologii : in 2 vol. Moscow, Nauka. Vol. 1.448 p. (In Russ.).

Khudiakov, Iu. S. (1983) Pogrebenie po obriadu trupopolozheniia. In: Istoricheskaia etnografiia: traditsii i sovremennost'. Vol. 2. Leningrad, Izdatel'stvo Leningradskogo universiteta. Pp. 141-148. (In Russ.).

Submission date: 28.02 .2017$.

Анжиганова Аариса Викторовна - доктор философских наук, доцент, профессор кафедры философии и культурологии Хакасского государственного университета им. Н. Ф. Катанова. Адрес: 655017, Россия, г. Абакан, ул. Аенина, А. 90. Тел.: +7 (390-22) 4-37-64. Эл. адрес: alv_9@mail.ru

Арчимачева Маргарита Юрьевна - старший преподаватель кафедры истории России Хакасского государственного университета им. Н. Ф. Катанова. Адрес: 655017, Россия, г. Абакан, ул. Аенина, д. 90. Тел.: +7 (390-22) 4-37-64. Эл. адрес: archimacheva.margarita@yandex.ru

Anzhiganova Larisa Valerievna, Doctor of Philosophy, Associate Professor, Professor, Department of Philosophy and Culturology, Katanov Khakass State University. Postal address: 90, Lenina St., Abakan, Russian Federation 655017. Tel.: +7 (39022) 4-37-64. E-mail: alv_9@mail.ru

Archimacheva Margarita Yurievna, Senior Teacher, Department of Russian History, Katanov Khakass State University. Postal address: 90, Lenina St., Abakan, Russian Federation 655017. Tel.: +7 (39022) 4-37-64. E-mail: archimacheva.margarita@yandex.ru 